\title{
The Role Of HR Managers In Developing Intellectual Capital: A Comparative Case Study And Viewpoints On Some Selected Companies
}

Nadir Kolachi, Skyline University, University City of Sharjah, UAE Obasi H. Akan, North Caroline A\&T State University, USA

\begin{abstract}
In modern times, the role of human resource (HR) managers has changed as HR policies are planned in accordance with the changing global environment. Their role has expanded to include team building and development of intellectual capital (IC). Workforce diversity has driven many CEOs and HR directors to develop a systematic method for dealing with and ensuring cooperation from the workforce in order to maintain organizational discipline. Rapid advancement, innovations, and changing business trends provide a platform for HR managers to formulate strategies and develop IC to lead the organization in a better manner.

This case study research proposes two models - Employees' Commitment Model (ECM) and Organizational Commitment Model (OCM) - which explain the methodology and techniques for developing IC in modern companies. Further, these models are applied to some selected companies. ECM pertains to developing an individual's IC, while OCM presents the organizational strategy for adopting and developing IC in modern companies. In a rapidly changing global environment, service-oriented activities are in high demand across sectors. Consequently, HR managers are willing to innovate and invest in IC. Management tools of training, coaching, dealing, and instilling a sense of ownership best develop a company's IC. Until a few decades back, companies invested in the production processes; later, the focus shifted to technology. Today, the focus is on workers' knowledge or investment in IC.
\end{abstract}

Keywords: Role of HR Managers; Intellectual Capital; Comparative Analysis; ECM and OCM

\section{INTRODUCTION}

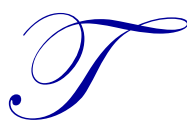

his study investigates the role of human resource (HR) managers in building intellectual capital (IC) by evaluating various situational dilemmas and creating a facilitative platform for developing IC. Mangers were compelled to develop IC to cope with rapid technological advancements and the financial crises in particular.

This study indicates that the role of HR managers is more demanding in modern organizations and has expanded beyond mere administration or staff management; they are now strategic partners who contribute toward achieving organizational objectives.

Further, this study highlights the steps taken by the HR managers at top companies for achieving organizational objectives and the yardsticks they use for developing IC. This will serve as a guideline for all HR managers and decision-makers in understanding the different roles of HR managers during managerial, technological, social, and financial crises. HR managers play an important role in a competitive world; therefore, the study of HR management (HRM) is increasingly viewed as a source of competitive advantage (Wright, Dunford, \& Shell, 2001). Mintzberg (1975) stated, "No job is more vital to our society than that of the Manager. It is the 
manager who determines whether our social institutions serve us well or whether they squander our talents and resources." According to Beer, Spector, Lawrence, Quinn Mills, and Walton (1984), "Human resource management involves all management decisions and action that affect the nature of the relationship between the organization and its employees - its human resources." They highlighted that a key factor that differentiated HRM from personnel was the strategic involvement of those managers who are connected with the newly named HR function. Their study has addressed all the managerial roles in the modern HR domain that pertain to significant investments in IC development. The role of HR is particularly important in steering the company in the right direction by investing correctly in developing IC. The concept of IC is not an old one, but it has gained prominence in recent years given the increased focus on asset integration. IC has also been defined as the difference between a firm's market value and the cost of replacing its assets. It typically refers to those aspects that generally cannot be valued in monetary terms, such as expertise, knowledge, and organizational learning ability (Bontis \& Nick, 1996). Market value equals book value plus IC, with book value usually only the tip of the iceberg of wealth (Miller \& William, 1999).

IC refers to the parameters for building and running a firm as per the firm's strategy. It comprises various factors as identified by different authors, but the three common factors are: 1) human capital that pertains to employee skills necessary for performing the assigned task; 2) structural capital that pertains to the company's systems, processes, and workflow automation; and 3) customer capital or relational capital that refers to the firm's rapport with customers, suppliers, government, and other community or regional entities. HR managers play a very important role as they hire talent who can apply their knowledge relevant to these parameters. In addition, they must ensure coordination among things as per the tactical plan. Besides, HR managers must also strive to build relationships between the company and the rest of similar or other entities in order to promote and build the company's image. Thus, the basic role of HR managers in today's times is to build social capital and developing IC.

The HR department must also help the other departments to create a knowledge warehouse as per the company's plans. It must then create a pool of employees who have knowledge of or are otherwise trained by the $\mathrm{HR}$ to use this warehouse in the most effective manner. While the company's foundation is important, HR development is the real key to successful operations. A company's HR department has varied functions. Besides IC development, it must liaise with all the other departments, execute quality human resource development (HRD) activities, collaborate with the top leadership and connect them with the middle hierarchy, and track the company's achievements. In particular, its role is crucial but productive in IC development.

\section{LITERATURE REVIEW}

The most important role of an HR manager is to induct and identify competency within the company. HR managers believe that competency is the basis for developing IC which drives a company's productivity. Competency comprises knowledge, abilities, technologies, political systems, and managerial and other values that provide organizations with a competitive edge that is perceived by clients and is difficult to replicate (Prahalab \& Hamel, 1990). The competency of American companies is their creativity, that of European companies is innovation, and that of Asian companies is their focus on relevant operations. The concept of supporting IC through competency has been subscribed by many philosophers.

In the 90s, many varied concepts of IC were proposed (Bontis, 2002, 2001, 1998; Edvisson \& Malon, 1997; Klien \& Prusak, 1994; Seemann et al., 2000). HR managers play a crucial role of collaborating with other departments to build good IC and create a conducive environment that ensures communication and teamwork across departments. This involves the integration of the information systems activities of the information technology (IT) department, the creativity of the marketing department, and the achievements of the other departments. Thus, building competency involves the integration of information systems, technological solutions, resources, abilities, and organizational memory (Gramine, 2007; Berends et al., 2006; Smith et al., 2005; Rolan et al., 2004). However, competency involves not only knowledge management, but also other activities, as indicated by the models proposed in this study.

The main role of the HR department in these competitive times is to ensure HR and organizational learning. It must maintain discipline in activities pertaining to managing, cooperating, orienting, and developing IC. This is possible through developing good relationships among employees and between the employer and employees in particular. 
Organizational learning refers to the process of improving organizational behaviors by acquiring and developing new knowledge and capabilities (Fiol \& Lyles, 1985). According to March and Olsen (1976), knowledge is a continuous process. Discipline and disciplinary rules have long been recognized as the key dimensions of the employment relationship (Edwards, 2005). The role of HR managers is never limited to recruitment; rather, they must ensure coordination among and utilization of employees through formal systems in the most effective manner. According to Pynes (2009, p. 3), "HRM is the design of formal systems in an organization to ensure the effective use of employees' knowledge, skills, abilities, and other characteristics (KSAOCs) to accomplish organizational goals." They supplement this broad definition with some specific HRM functions such as "recruitment, selection, training and development, compensation and benefits, retention, evaluation and promotion of employees, and labormanagement relations within an organization."

HR managers must manage all the organizational systems to maintain discipline and build an employee base. The typical functions of the HR department are "planning, acquisition, development, and discipline" (Klingner, 2009, p. 3). The HR department plays a strategic role as it drives the process of training employees and building an employee base. While there may be several unique approaches to strategic planning, the components of a strategic plan are typically consistent. Jackson (2007) and Woolridge (2004) indicate that a strategic plan must include 1) an organizational profile that presents relevant information about its operations, history, successes, challenges, and applicable statistical data; 2) an environmental analysis that identifies the external factors to be considered; and 3) projections for these peripheral elements. HR managers must induct knowledge workers who not only deliver good results, but also influence other employees to improve in various aspects. Knowledge workers are defined as those who possess great problem-solving abilities and a high level of IC in the form of specialized tacit knowledge (Mitchell \& Meacheam, 2011). Knowledge workers, IC, and talented employees are extremely important for a company's success. However, knowledge and skills are becoming increasingly scarce (Tan, 2008). Mature knowledge workers are valuable sources of experiences and knowledge; consequently, HR managers must strive to prolong the work life of mature workers (Callahan, Kiker, \& Cross, 2003).

In a rapidly changing knowledge environment, it is essential to provide quality training programs to maintain employees' employability. Training, coaching, and mentoring are routine functions of the HR department that build the IC of a company. Since learning increases human capital (Lazear, 1998), organizations must train and develop workers in a rapidly changing working environment (Wild, Griggs, \& Downing, 2002; Beaver \& Hutchings, 2005; Ong \& Lai, 2006; Griffin, 2011).

\section{ROLE OF HR MANAGERS IN DEVELOPING INTELLECTUAL CAPITAL}

While the role of HR managers in IC development was always considered crucial, it has gained greater prominence in the current century with regard to people management and development, as companies need to identify the right person with the right skills to perform the job in the right manner.

This study proposes two models - Employees' Commitment Model (ECM) and Organizational Commitment Model (OCM) - that explain the role of the HR department in IC development. The ECM is a selfmaintaining process through which employees build competence and commitment. OCM indicates the company's efforts toward employee development so that they perform their job in the right manner. This case study has organized both models in a manner that the role of HR in building IC is evident. ECM is an individual-centric model; that is, individuals are responsible for self-development so that they can contribute to the company. OCM is concerned with the organizational strategies for motivating, building, and guiding employees in order that they perform well. Technically, the purpose of both the models is the same and is achieved through the efforts and tactical involvement of the HR managers. The role of HR in ECM is based on strategies that mold individuals as per organizational objectives, while OCM is geared toward strategies that enhance employee performance.

\subsection{Organizational Commitment Model}

Figure 1 presents the OCM structure and detailed organizational perspectives on internal IC development, including the crucial role of HR managers in IC development for achieving desired goals. The second column in Figure 1 enlists the seven key roles of HR managers in IC development. These roles are analyzed, innovated, and recorded for developing IC which helps the company achieve the desired success. While there are several roles that 
HR managers play in the IC development process, the seven roles presented in the figure are the most crucial. The third column indicates that IC ultimately leads to organizational success. The second row at the bottom of Figure 1 indicates the role of HR managers in bridging the gap between organizational behavior and organizational theory.

Organizational behavior is the behavior of employees toward the organization that the latter need to control, handle, and mange. The HR managers play a role in doing so through the image, objectives, and development of intellectuals within the company. Organizational theory is the behavior of the company toward its employees. Here, the HR managers play a tactical role in managing the relationship between the employees and the employer which aids the development of IC in the company.

\begin{tabular}{|c|c|c|}
\hline 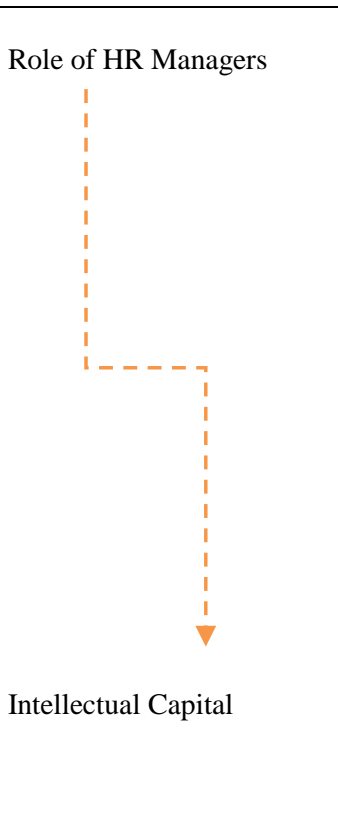 & 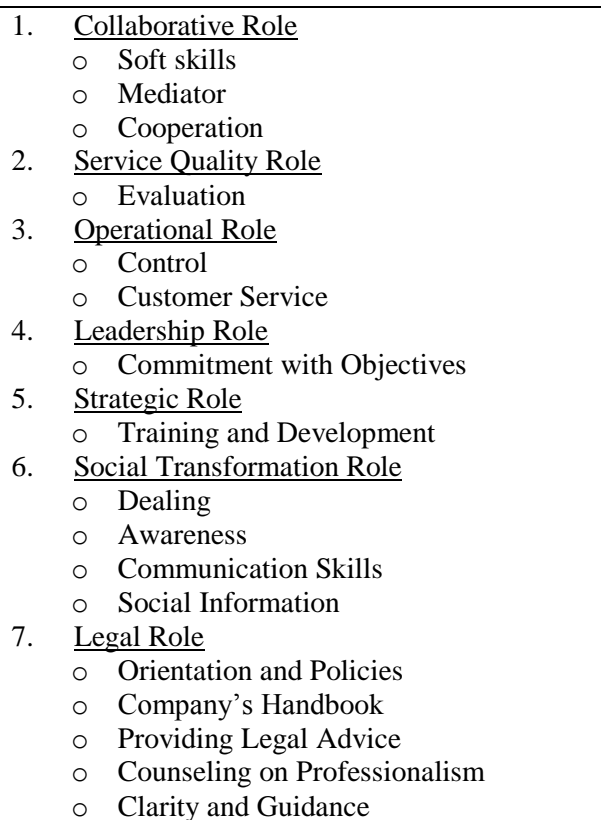 & $\begin{array}{r}4 \\
\vdots \\
\vdots \\
\vdots \\
\vdots \\
\vdots \\
\vdots \\
\vdots \\
\vdots \\
\vdots \\
\vdots \\
\vdots \\
\vdots \\
\vdots \\
\vdots \\
\vdots \\
\text { Organizational Success }\end{array}$ \\
\hline Organizational Behavior & Human Resource Management & Organizational Theory \\
\hline
\end{tabular}

Figure 1: OCM (Organizational Commitment Model)

\subsubsection{Collaborative Role}

The HR department is the hub of the organization. The key characteristics of an organization are its people and the main role of any department is to equip people with the knowledge necessary to perform tasks. If the tasks are performed in the best possible manner, the company can achieve good results and positive responses from its customers. Thus, HR managers are responsible for developing collaboration among the employees, the employer, and the concerned tasks. Such collaboration is achieved through a combination of both soft and hard skills; the latter pertain to the defined strategies of the company. The HR managers cooperate with, help, and mediate between employees. This shows their concern for employees and IC development.

\subsubsection{Service Quality Role}

The HR department is constantly examining and evaluating best management practices as per the demand, constraints, and plans of the company. Management practices are the key difference between successful and unsuccessful companies. The HR managers evaluate, identify, and implement the best practices in their company with the cooperation of the company employees.

\subsubsection{Operational Role}

The two factors crucial for organizational success are customer service and control. Control refers to controlling the operations, tasks, service delivery, anger, listening skills, technology, and wastage of companies' 
resources. HR managers must fulfill both these roles - the former in conjunction with the top hierarchy and the latter through coordination with the employees, particularly those from the sales and marketing department. This requires dealing with employees and customers with great attention and care.

\subsubsection{Leadership Role}

HR leadership programs are a success at several top-ranking MNCs. The HR department identifies potential employees who are talented and can be utilized as change agents. It educates these employees about the company's vision and the commitment required to achieve it. Total commitment is crucial to achieving phenomenal results. General H. Norman Schwarzkopf stated, "Leadership is the combination of strategy and character. If you must be without one, be without the strategy." Thus, the character of the HR manager is crucial to employee development - a fine character will build another fine character. The HR department must commit to developing good leaders, role models, change agents, and employees who will support its efforts.

\subsubsection{Strategic Role}

T\&D programs are strategic activities of a company for which the HR collaborates and coordinates with the top management and ensures good linkages between the top, middle, and lower level employees. Training is an important aspect and training needs assessment (TNA) helps to determine the kind of training programs required in an organization.

\subsubsection{Social Transformation Role}

This role changes with the changes in technology, trends, traditions, norms, and workforce diversity. The HR department understands the social patterns and requirements of employees and plans, helps, and guides them accordingly. It creates awareness about the company's HR programs, career development plans, and benefits of being talented. This motivates employees to put greater efforts to achieve company goals and further their careers as well, which, in turn, leads to IC development. The HR department also communicates with employees through social media and other networks, thereby creating awareness about its soft and hard roles in the company. Consequently, employees are more disciplined and informed about the happenings in the company.

\subsubsection{Legal Role}

The HR department can assist employees in understanding legal aspects including policies, rules, regulations, successes, and concerns. Employee awareness about the company's successes and failures is essential for their development. The HR manager guides and helps employees to set personal objectives that support the company's objectives as well. They educate employees about the company handbook, including the training programs, and create employee awareness about the company's plans and strategies. Further, they support and counsel employees - those who are more motivated when counseled and supported within the constraints. Having clarity and guidance in company matters will help all employees and the environment will be much cordial in dealing with people.

OCM can help companies over the long term if the HR managers can fulfill their roles as per the model's parameters. This case study has innovated, organized, evaluated, and recorded those parameters that are potentially the best means for developing the company's IC.

\subsection{Employees' Commitment Model}

Figure 2 explains the commitment of employees to boss, company, work, and self. Modern corporations place great emphasis on educating employees about their vision and mission that indicate the company's current and future status. However, mere knowledge of the vision is insufficient; employee commitment toward company strategies is equally important. This is achieved through self-development. ECM aims at the intellectual development of every employee; that is, individuals must enhance their capabilities in order to achieve company objectives. Thus, employee talent and ownership are important factors. Modern successful companies are driven by the commitment of their entire workforce, from the top to the bottom level employees. 


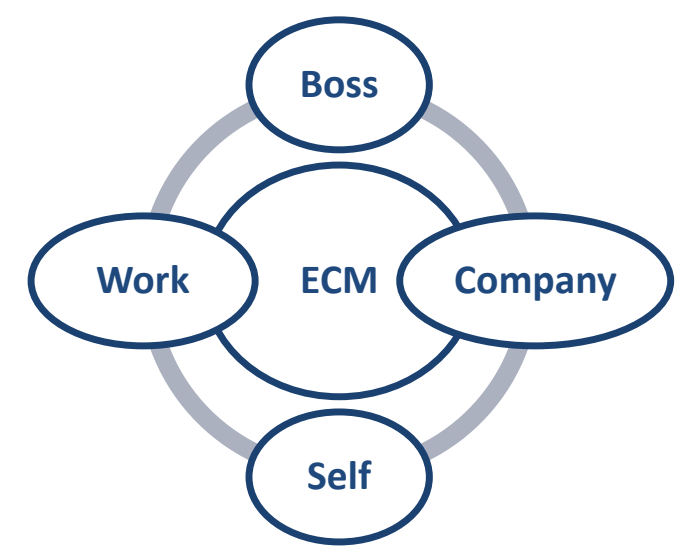

Figure 2: ECM (Employees' Commitment Model)

ECM guides managers to obtain full commitment from employees. While there are several tools like ECM, the latter is a proven management practice that is potentially top priority for modern managers. ECM comprises four important factors - boss, organization, work, and self. Employee compliance with these factors is a sign of IC development at the individual level. There are also sub-factors that aid the IC development process.

\subsubsection{Boss}

Employees' commitment toward the boss is essential for organizational discipline. Employees must remain focused on organizational achievements. In this regard, they need to collaborate with the boss in order to foster teamwork and enthusiasm toward work performance. Collaborating with bosses has varied meanings - awareness about company concerns will ensure leadership with employees and bosses as employees will then work for the organization's benefit. Employees must commit to working in collaboration with their boss and vice versa. This will definitely lead to a cordial working environment that will drive the organization's prosperity and steer it in the right direction. Top organizational leaders, like Jack Welch (General Electric), Bill Gates (Microsoft), and Wayne (China Mobile), have always promoted a collaborative environment and appreciated employee commitment in this regard. A sub-factor of employee commitment toward the boss is to execute his orders. Employee commitment is not only about work focus but also acceptance and execution of orders for the smooth flow of sequential tasks in the company.

\subsubsection{Organization}

Employee commitment toward the organization must be such that they must be as concerned about the organization as they are for their homes. Employee commitment begins with a sense of ownership - employees must always be concerned about the company's successes and failures. This is highly prevalent in top companies where employees claim that they do not merely work for the company; rather, they own the company and are sincere about it. Employees' sense of ownership makes the company a good place for employees. In addition, employees must act as spokespersons of the company and present the organization in a positive light. This role of spokesperson has been identified by several authors. Organizational citizenship is another aspect where employees display their commitment toward being good organizational citizens by compromising, sacrificing, helping, and supporting each other for organizational benefit. This involves appropriate utilization of the company's time to ensure success and outdo competitors. As Halford E. Luccock stated, "No one can whistle a symphony. It takes an orchestra to play it." Teamwork is an important focus area for companies; it requires employee commitment toward becoming team players.

\subsubsection{Work}

The pillars of the ECM are commitment to boss, organization, and work. Commitment pertains to employee sincerity and love toward work. Responsibility is the first aspect of work commitment. Responsibility is the inner conviction of a human being that relaxes and eases the tensions of life. Life is very relaxed if employees 
display responsibility. Employees must show commitment to the tasks for which they are hired by the company and must repay the company for the care it takes and the compensation it pays them. Employees must work properly, meet deadlines, and display enthusiasm toward achieving company objectives. If all the employees display commitment and accept complete responsibility, then the company will definitely achieve its objectives. The second aspect is ethics. Employee commitment to ethics is crucial, but few employees focus on how they affect the quality of the working environment. Best ethics involve avoiding personal calls at the workplace because one is committed to the company for eight hours. The third aspect is prudence where employee commitment is so high that they try to do something extra for the benefit of the organization and steer it in the right direction, even if they are not paid for it. Prudence refers to additional efforts by employees for the company's good.

\subsubsection{Self}

Employee commitment is essential toward not only the company, but also self; consequently, employees are comfortable, relaxed, and healthy. An employee is energetic and motivated if he carries out his activities in a systematic manner. The first aspect of employee commitment toward self is career development - employees must be concerned about their career as well. The second aspect is learning - employees must show commitment and learn new things that may help them to contribute to the company's success. Good employees strive to learn and gain knowledge and experience that they can apply for the betterment of the company. The third aspect is growth, which pertains to self-actualization - employees must accept challenges, take risks, and accept responsibilities in order to achieve exceptional results. Employee commitment toward growth is important because they can then contribute to the company's betterment in the best possible manner. This approach drives employee ambition to steer the company to the top and make it the most successful company. If all employees make efforts, are ambitious, and committed toward self, then the company undoubtedly reaches the pinnacle of progress and enjoys long-term success.

\section{ECM AND OCM NORMS}

Table 1 presents a comparative analysis of the key factors that depict organizational commitment in modern and traditional organizations based on a survey of several top CEOs and Managing Directors.

Table 1: Role of HR in ECM and OCM

\begin{tabular}{|c|c|}
\hline Modern Companies & Traditional Companies \\
\hline$\underline{\text { Role in ECM }}$ & $\underline{\text { Role in ECM }}$ \\
\hline 1. Sense of ownership & No sense of ownership \\
\hline 2. Prudence & Lack of prudence \\
\hline 3. Counseling with support & Counseling without support \\
\hline 4. Accountability & Responsibility \\
\hline 5. Adoptability & Avoidance \\
\hline 6. Collaborative Skills & Lack of Collaborative Skills \\
\hline 7. No boss, more work & No boss, no work \\
\hline 8. Boss is like a colleague & Boss is king \\
\hline 9. Employees are partners & Employees are merely workers \\
\hline 10. Social gatherings for discussing company concerns & $\begin{array}{l}\text { Social gatherings for discussing issues that are unrelated to } \\
\text { the company }\end{array}$ \\
\hline$\underline{\text { Role in } O C M}$ & Role in $O C M$ \\
\hline 11. Focus on producing leaders & Focus on producing followers \\
\hline 12. Management by Objectives (MBO) & Management by Organization \\
\hline 13. Management by Working (MBW) & Management by Eating (MBE) \\
\hline 14. Meetings at breakfast time & Meetings at lunch time \\
\hline 15. Employee union behaves like employees & Employee union behaves like separatists \\
\hline 16. CEO is surrounded by Employees & CEO is surrounded by Directors, Heads \\
\hline 17. Training for required skills & Training for any skills \\
\hline 18. Focus on the types of training & Focus on the number of trainings \\
\hline 19. Training with responsibility & Training with incentives \\
\hline
\end{tabular}


As mentioned earlier, a sense of ownership is the first step in good companies. They must educate employees about the importance of displaying a sense of ownership and guide employees to achieve organizational objectives. Successful companies are those whose employees are enthusiastic, committed, and prudent. Good employees are always inclined to do and contribute to the company's betterment. Prudence is a natural motivation and sometimes people are influenced by the salutary nature of the people around them. Top companies encourage employees to adopt such good habits. Good bosses and colleagues believe that it is essential to maintain a prudent environment that influences employees to help one another.

The next comparison pertained to the organization's attitude toward counseling employees and vice versa. It is obvious that good companies and bosses provide reasonable and suggestive counseling followed by support. Some companies remained unsuccessful because they were unable to provide support to the employees postcounseling. For example, some employees are always interested in the betterment of the company but need counseling and guidance from their bosses or senior colleagues in this regard. Good companies always counsel and support such employees.

Accountability is another important aspect that good companies must understand. In certain countries where ethical standards are mere concepts and not the culture, organizations have to rely on accountability; that is, it is important to check that employees are fulfilling their responsibility. Among the varied management practices and proven management styles, collaborative skills are very important in today's times. Reputable companies always encourage collaborative skills and this is possible only if someone has good communication skills. Talented bosses keep employees closer so that they can understand their concerns. Organizations maintain an open environment where everybody has a fair chance to display their performance and establish their presence.

The next aspect is related to the boss's presence and work continuity. While good organizations maintain a good working environment that ensures work continuity, employees in certain less professional organizations do not work if the boss is not around. Good employees continue to work during working hours, regardless of their bosses' presence. Such motivated employees will surely contribute to organizational success.

Another similar aspect is if the boss behaves like a colleague and not a boss. In an employee-centric environment, employees are committed and will steer the company in the right direction. Further, it is important that employees are not considered as merely workers, but are recognized as partners. In addition, companies must arrange social gatherings where employees can interact with each another. This is based on Abraham Maslow's hierarchy of social needs. Such a facilitative platform can create and enhance a cordial atmosphere among employees. While all companies generally organize social gathering opportunities for employees, they do not achieve the same results. As per our survey, MNCs regularly arrange social gatherings where their employees discuss company-related concerns, issues, opportunities, and business exposure. Bosses, divisional heads, managers, and employees interact to check and obtain input from each other at such gatherings. On the contrary, some traditional companies discuss unproductive topics, like politics and negative issues, at social gatherings. According to Ralph Nadar, "The function of leadership is to produce more leaders, not more followers." Similarly, good organizations aim to produce good leaders as compared to traditional organizations that produce only followers. Organizations need to instill a sense of leadership and sincerity among employees and not just produce followers.

Further, MBO is a common tool through which MNCs achieve mutually agreeable goals, increase employee participation, and build an environment of trust. While MNCs use MBO as a motivational and training tool, traditional companies focus on Management by Organization - a term coined by the authors of this study that refers to merely implementing a monitoring policy. Some companies are also implementing MBW that deals with the working ethics of employees. Good companies have adopted and implemented MBO and MBW to achieve their respective visions; however, their employees also need to be motivated and inspired to follow MBO and MBW. Another aspect highlighted by this survey was the importance of meetings. Generally, several meetings take place within companies, but few of them are productive.

Regarding unions, the survey indicates that globally, no company wants unions as they are perceived as troublemakers who never implement management orders. However, unions can play a positive role if they assist in identifying certain issues. Another interesting aspect pertains to employee interactions with the bosses; generally, 
employees, particularly those at the mid and lower level, rarely get a chance to interact with the bosses due to time or priority constraints. This typically happens in traditional or bureaucratic companies; in good companies, bosses focus on frequently meeting employees. This is seen in many top organizations like Microsoft, IBM, Toyota, and China Mobile.

\section{APPLICATION OF ECM AND OCM ON SELECTED COMPANIES}

\subsection{Application and Viewpoints on American Companies}

American companies are the creation of accurate leadership and high business-mindedness - an approach that led to their global dominance and generated huge customer response. OCM is the correct application with regard to employee commitment in the areas of self-development, organizational concerns, and work styles. The role of HR managers at American companies is based on self-development as companies create a facilitative platform for their employees to innovate and apply modern techniques and generate profits for the company. The HR managers in American companies play an important role in creating awareness about the company's mission and vision, counseling employees, and providing huge moral, organizational, technical, and authoritative support. Consequently, American companies are more successful than their other global counterparts.

OCM is partially used at American companies. Companies like Microsoft, Google, General Electric, and IBM are popular because their leaders inspired many others. These companies applied OCM and are fully compliant with the leadership, strategic, and legal aspects of the model. American companies are pioneers in using social transformation activities. Their HR managers are constantly using social media for various functions such as recruitment, selection, interviews, training, mentoring, and other relevant meetings.

The HR department is the hub for all functions and coordination at all levels. The HR managers are clear about the TNA process and prefer to induct trained people and later identify if they have any further training needs. The collaborative environment is much appreciated in modern American organizations as it promotes trust and organizational development.

\subsection{Application and Viewpoints on European Companies}

European companies are unique because they believe in organizational commitment rather than leadership and self-development. Only a few parameters of the ECM model, like boss, company, and work, are used. The HR managers at European companies ensure that employees are extremely committed toward working for organizational benefit and that the bosses are comfortable in this regard. European companies, like ENI, British Petroleum, and Operations of TOTAL in EU, follow OCM to an extent.

OCM is widely used and applied in European companies, although factors such as service quality, strategies, and legal roles are prominent. The HR managers strongly believe that such factors have contributed to the success of European companies. They utilize employees for strategy innovation to help companies achieve their desired goals. They inspire employees to provide quality service - an aspect that is considered sacred by European companies. They coordinate with the other departments to ensure that they provide high quality service. They have faced certain legal issues as well; consequently, they now ensure that their employees are updated on legal aspects to avoid reputational repercussions. The HR managers believe that such interactions help employees build a positive image of the company and, consequently, lead to IC development, which provides the company with a competitive edge.

\subsection{Application and Viewpoints on Asian Companies}

The role of HR managers and application of OCM and ECM on Asian companies reveals two aspects OCM aspect of sense of ownership and control and ECM aspect of commitment to the company. Asian companies strongly focus on employee commitment and sense of ownership. The role of the HR department in these companies is to control the identification that is based on the talent and inspire them to join the company. They believe that attracting talented employees will drive the company's IC development. 
Asian companies also emphasize on controlling the wastage of companies' resources. Employee commitment toward the organization is very important, particularly in Japan. They must consider the organization as a place of worship that provides them their means of living. Japanese companies emphasize on teamwork and believe that teamwork brings success. Teamwork leads to idea generation; while different ideas can lead to conflicts, teamwork undoubtedly improves the quality of ideas. Employees must show commitment in all aspects and provide quality ideas for the betterment of the company. They must build trust and support and create a good working environment to achieve company goals.

\section{RESEARCH METHODOLOGY}

This study focuses on the role of HR managers in IC development. It employs a basic, qualitative case study methodology and the findings are based on the models constructed for this study and a survey of selected companies.

This study proposes two models for building and developing IC in modern companies. The models are based on the results, primary sources, and author's priori interest in the field. A qualitative case study approach was employed given the nature of the study topic and the variety of companies under consideration. Various other authors have also considered this approach as appropriate (Yin, 1994; Flyvbjerg, 2006; Eisenhardt, 1989; Merriam, 1994). Qualitative methods are characterized by the closeness to the data. They are often based on a holistic perspective (Reichardt \& Cook, 1979, in Ghauri \& Gronhuag, 2005). The models are designed based on the roles of HR managers who are steering modern companies in the right direction, particularly with regard to IC Development, and their application to selected companies is examined. Certain participants' opinions on the models and companies were also taken into consideration. These participants included business executives, IT managers, HR managers, CEOs, and CIOs. The choice of companies was a function of the convenience of applying the model and gathering input pertaining to IC development in modern companies.

The main propositions of this case study are derived from the comparative analysis of the selected companies and the models constructed for the study. The propositions from the models were positive. ECM has attracted much attention from HR managers and propositions regarding the role of HR managers are evaluated and recorded in the OCM. The proposed models are described, explained, and justified using priori interest, primary sources, secondary sources, and sources of application with viewpoints on selected companies.

\section{CASE STUDY RECOMMENDATIONS}

- $\quad$ The proposed models may be the best tools for building employer-employee relationships and developing IC in modern companies. Companies can employ these models to deal with competition, changing customer trends, global recession, and employee commitment issues.

- $\quad$ Companies must invest in IC development and provide guidelines to employees about company objectives through focused and customized training on ECM and OCM aspects.

- $\quad$ Companies must invest in instilling greater knowledge and accountability in employees so that they perform as per the strategy book. Some managers explain everything in the handbook but forget that it may yield no response from employees. Employees need to be updated, trained, informed, and oriented toward working for the company's objectives.

- HR managers must exercise caution when providing guidelines to employees on policies, rules, regulations, and other important information.

- $\quad$ Companies must develop resources that provide accurate information about competitors' strategies so that they can achieve goals better than their competitors do. This requires HR managers to put in greater efforts to entice customers, collaborate with suppliers, understand competitors' strategy, and gauge the sensitivity of their own employees.

\section{CONCLUSION}

This study found that OCM and ECM are important to IC development in modern companies. It indicates that the proposed models comprise various parameters that can be applied as per companies' constraints and that 
compliance with these models drives their progress. The study also found that American companies prefer leadership focus, European companies prefer organizational commitment, and Asian companies expect sense of ownership from employees.

The models proposed in this study can be evaluated and applied to any business or company and are comparable with other IC development models. This study concludes that modern companies can build IC by adopting ECM and OCM and orient their employees toward the same. Further, HR managers play a crucial role in building IC in modern companies.

\section{AUTHOR INFORMATION}

Dr. Nadir Ali Kolachi is a Professor of Management and HRD at Skyline University, University City of Sharjah, UAE. He has 20 years of training, teaching, consultancy, and research experience at national and international levels. Dr. Kolachi has earned an MBA, MS and PhD in Management. He has delivered various Keynote speeches and research presentations on HRM, Management, OD, Business Education, Public Administration, Leadership and Organizational Communication in the USA, UK, Poland, Italy, Portugal, Pakistan, India, and UAE. Dr. Kolachi is also a certified corporate trainer of GAMMP International (Global Association of Management and Marketing Professionals). E-mail: nadir.kolachi@gmail.com (Corresponding author)

Dr. Obasi H. Akan is a Professor of Organizational Behavior and Management at North Carolina A\&T State University, Greensboro, USA. He has over 15 years of experience in teaching and training at the University level. Dr. Akan has taught all Management and HR-related subjects to BBA/MBA/MS/PhD students, delivered Keynote speeches and provided training in many countries, and he served as Session Chair, Reviewer, Editor and Member of the Academic Board at various places. He also has over 30 years of experience in personnel management for the Federal Government including the Board of Governors, Federal Reserve System, Office of Personnel Management (OPM), The Department of Commerce, and The National Aeronautics and Space Administration (NASA) headquarters and field centers.

\section{REFERENCES}

1. Aitchison (2007). The ability of HR professionals to play a more strategic role in an organization is their lack of certain competencies.

2. Bontis, N. (1998). Intellectual capital: An exploratory study that develops measures and models. Management Decision, 36, 63-76.

3. Bontis, N. (2001). Assessing knowledge assets: A review of the models used to measure intellectual capital. International Journal of Management Reviews, 41-60.

4. Bontis, N. (1996). There's a price on your head: Managing intellectual capital strategically. Business Quarterly, 60(4), 40-47.

5. Callahan, J. S., Kiker, D. S., \& Cross, T. (2003). Does method matter? A meta-analysis of the effects of training method on older learner training performance. Journal of Management, 29(5), 663-680.

6. Edwards, P. (2005). Discipline and attendance: A murky aspect of people management. In Managing human resources, personnel management in transition ( $4^{\text {th }}$ ed.). Willey-Blackwell.

7. Edvinsson, L., \& Malone, M. (1997). Intellectual capital: Realizing your company's true value by finding its hidden brainpower. New York: Harper Collins Publishers, Inc.

8. Fiol, M. C., \& Lyles, M. A. (1985). Organizational learning. Academy of Management Review, 10, 803813.

9. Gramigna (2007) Model of competency. Pearson Prentice Hall.

10. Jackson, P. M. (2007). Nonprofit strategic planning: Leveraging Sarbanes-Oxley best practices. New Jersey: John Wiley and Sons.

11. Klien \& Prusak (1994) working paper. Center for Business innovation NY

12. Klingner, D. E. (2009). Competing perspectives on public personnel administration: Civil service, patronage, and privatization. In S. W. Hays, R. C. Kearney, \& J. D. Coggburn (Eds), Public human resources management: Problems and prospects. New York: Longman.

13. Miller, W. (1999). Building the ultimate resource. Management Review, 88(1), 42-45. 
14. Mitchell, R., \& Meacheam, D. (2011). Knowledge worker control: Understanding via principal and agency theory. The Learning Organization, 18(2), 149-160.

15. Prahalad, C. K., \& Hamel, G. (1990). The core competence of the corporation. Harvard Business Review Journal, May-June, 79-91.

16. Pynes, J. E. (2009). Human resources management for public and nonprofit organizations: A strategic approach ( ${ }^{\text {rd }}$ ed.). San Francisco: Jossey-Bass.

17. Rolan (2004). Managing organization forgetting. MIT Sloan Management Review, 45(2), 45-51.

18. Smith (2005). Existing knowledge, knowledge capability. Academy of Management Journal, 346-357

19. Tan, F. M. (2008). Organizational support as the mediator of career-related HRM practices and affective commitment: Evidence from knowledge workers. Research and Practice in Human Resource Management.

20. Woolridge, B. (2004). Preparing public administrators for an era of globalization and decentralization: A strategic-contingency approach. International Review of Administrative Sciences, 70, 385-403.

21. Wild, R. H., Griggs, K. A., \& Downing, T. (2002). A framework for e-learning as a tool for knowledge management. Industrial Management and Data Systems, 102(7), 371-380. 